Purdue University Purdue e-Pubs

2011

\title{
How information literacy becomes policy: An analysis using the Multiple Streams Framework
}

Sharon A. Weiner

Purdue University, sweiner@purdue.edu

Follow this and additional works at: http://docs.lib.purdue.edu/lib_fsdocs

Part of the Library and Information Science Commons, and the Political Theory Commons

\section{Recommended Citation}

Weiner, Sharon A., "How information literacy becomes policy: An analysis using the Multiple Streams Framework" (2011). Libraries Faculty and Staff Scholarship and Research. Paper 70.

http://dx.doi.org/10.1353/lib.2011.0037

This document has been made available through Purdue e-Pubs, a service of the Purdue University Libraries. Please contact epubs@purdue.edu for additional information. 


\section{How Information Literacy becomes Policy:}

\section{An Analysis Using the Multiple Streams Framework}

Sharon Weiner, EdD, MLS, AHIP

Professor and $W$. Wayne Booker Chair in Information Literacy

Vice-President, National Forum on Information Literacy

Purdue University Libraries

504 West State St.

West Lafayette, IN 47906

765.496 .3128 (phone)

sweinerepurdue.edu

\section{Bio:}

Sharon Weiner, EdD, is Professor of Library Science and W. Wayne Booker Chair in Information Literacy at Purdue University. She has been the Dean of Library Services at the University of Massachusetts Dartmouth, Director of Peabody Library at Vanderbilt University, and a department head in the Health Sciences Library at the University at Buffalo. She received her EdD in Higher Education Leadership and Policy Studies from Vanderbilt University and her MLS and BA from the University at Buffalo. 


\section{Abstract}

There is growing recognition that information literacy is a critical skill for educational and workplace success, engagement in lifelong learning, and civic participation. To be considered for allocations of financial and human resources, information literacy must become a policy priority for institutions and societies. Although there has been some progress in this area since 1974, when the term was coined, information literacy is not yet a priority for many organizations or governments.

There is no published examination of factors that may influence the adoption of information literacy as a policy priority. This paper explores aspects of the policy process from a U.S. perspective that can favor or impede the inclusion of information literacy on political agendas. It examines these questions through the Multiple Streams framework of policy

processes. It proposes recommendations to help those who advocate for information literacy to effect policy changes. It identifies areas for research that would help information literacy policy advocates demonstrate need. 


\section{Introduction}

This paper considers the introduction and adoption of information literacy as public policy from a U.S. perspective using the Multiple streams framework. This framework consists of the triad of problems, policies, and politics.

Public policy-making consists of processes that include the setting of an agenda; the identification of alternatives from which a choice can be made; an authoritative choice among those alternatives; and the implementation of a decision (Kingdon, 2003). An agenda is "the list of subjects or problems to which governmental officials, and people outside of government closely associated with those officials, are paying some serious attention at any given time" (Kingdon, 2003). Several factors may influence agendas:

- The political events that are currently prominent (Zahariadis, 1999)

- Compelling societal problems (Zahariadis, 1999)

- The positions of elected officials (Zahariadis, 1999)

- Policy specialists, who generate policy proposals as they gain new knowledge and perspectives (Kingdon, 2003)

- Changes in national mood and public opinion (Kingdon, 2003)

- Changes in governmental administration and turnover in Congress (Kingdon, 2003) 
The public policy process is dynamic and complex. "Policymakers frequently face dynamic and shifting environments where ambiguity is rampant and where decision outcomes appear to be beyond anyone's control. Complexity, fluidity, and fuzziness are particularly appropriate characterizations of policy-making at the national level" (Zahariadis, 1999). There are several reasons that the process is complex. It consists of many people and groups from a variety of sectors including government agencies, legislatures, research, journalism, and the public. They have differing values, interests, perceptions, and preferences. Many existing or proposed programs are related; a policy change would, therefore, have an impact on them. "A final complicating factor in the policy process is that most disputes involve deeply held values/interests, large amounts of money, and, at some point, authoritative coercion" (Sabatier, 1999). Studies focused on the policy process in the U.S. indicated that it usually took at least ten years (Sabatier, 1999).

There has not yet been an examination of policy factors that may influence the adoption of information literacy as a public policy priority. What aspects of the policy process can favor or impede the inclusion of information literacy on political agendas? This paper will examine this question through one political science framework. It will propose 
recommendations to help those who advocate for information literacy to effect policy changes. It will propose areas for research.

A framework helps to identify the elements of a situation or problem and their relationships. "Frameworks organize diagnostic and prescriptive inquiry...They attempt to identify the universal elements that any theory relevant to the same kind of phenomena would need to include. Many differences in surface reality can result from the way these variables combine with or interact with one another. Thus, the elements contained in a framework help analysts generate the questions that need to be addressed when they first conduct an analysis" (Ostrom, 1999). This paper draws on the Multiple Streams Framework to better understand the policy process in relation to information literacy. This understanding can be a foundation for effective action in the future and can stimulate needed research.

\section{Multiple Streams Framework}

In the study of public policy formation in the United States, the Multiple Streams framework is one of the most popular and provocative (McLendon, 2003). Its origin was the organizational theory of March (cite). It can be helpful in explaining why policies gain importance on agendas or languish (Zahariadis, 1999). Multiple Streams has been used to explain such public 
policy issues as reading (Young, Shepley, and Song, 2010); merit aid (Ness, 2010); lottery scholarships (Ness and Mistreta, 2009); college student retention (Brown, 2007); and school sports (Houlihan, 2006). The only known application of Multiple Streams in library and information science was an examination of the policy development of the ERIC and MEDLINE databases (Weiner, 2009).

Multiple Streams differs from other theories of the public policy process in that it can describe relationships between policy issues and their environment, but also looks for causal linkages (McLendon, 2003). The Multiple Streams framework "suggests multifaceted processes in which problems, ideas, and politics combine with choice opportunities to move issues onto the decision agenda of the national government" (McLendon, 2003). This framework can apply to a wide variety of policy arenas (Sabatier, 1999) and can be useful for describing how policies are made when there is ambiguity, lack of clarity, and lack of self-interest. The Multiple streams framework can help to develop strategies (Zahariadis, 1999).

\section{Problems, Policies, and Politics Streams}

Kingdon identified three streams that flow through the political system: problems, policies, and politics. They are separate from each other and have individual dynamics and rules (Kingdon, 
2003). Policymakers pay attention to problems because they learn about certain conditions. For instance, indicators can reveal that there is a problem and they can measure change in a problem. Evaluation studies and letters from constituents that provide feedback about existing programs can draw attention to a problem. Classifying a situation as a problem involves interpretation, perception, value judgments, and beliefs (Zahariadis, 1999) .

The essential aspects of ideas that become policies are that they are technically feasible and that the values they represent are acceptable to policymakers. Ideas undergo a vetting process through discussion, papers, and hearings. During this process, an idea may change, couple with another idea, or disappear (Zahariadis, 1999).

The politics stream consists of the national mood, pressure group campaigns, and administrative or legislative turnover (Zahariadis, 1999). Politicians can monitor the national mood through opinion polls or interest groups. Legislative or administrative turnover can affect agendas. "The combination of the national mood and turnover in government exerts the most powerful effect on agendas" (Zahariadis, 1999). Serendipity and politics can cause policies to change or be reversed, depending 
on different combinations of problems, solutions, and politics (Zahariadis, 1999).

Merging the three streams of problems, policies, and politics can greatly increase the chance that policy makers will give an issue serious attention (Kingdon, 2003). Ignoring a stream can result in an unchanged agenda (Brown, 2007).

\section{Agendas}

For an issue to become an agenda, more than one stream needs to be joined at a critical point. These moments are called policy windows and are opportunities to focus attention on particular problems. Timing is crucial because it influences which problems, policies, or politics are in the forefront at any particular point. Windows can open in the problem stream or in the politics stream. They can be predictable or unpredictable and usually have limited duration. There are several reasons that windows might close:

- Policymakers might feel that they addressed the issue.

- No actions related to the proposed policy occurred.

- There was no alternative for making a decision about the policy.

- The people who caused the window to open no longer have power. 
- A critical event has passed (Zahariadis, 1999)

Windows are an important means of raising the awareness of policy makers to potential agenda items. A window can open when a policy is successfully adopted in one political arena, such as a state. If the policy is perceived as successful or broadly popular, elected officials in neighboring jurisdictions may want to adopt that policy. Those who are seeking election may be receptive to these policies to show that they are responsive to public preference. Elected officials may want to be perceived as leaders in policy areas, and so may become interested in innovative policies (McLendon, Heller, and Young, 2005).

When windows open, policy advocates must invest "time, energy, reputation, money-to promote a position for anticipated future gain" (Kingdon, 2003). They must act quickly and be persistent. "They must be able to attach problems to their solutions and find politicians receptive to their ideas" (Zahariadis, 1999).

\section{Alternative Policies}

Policy decision-makers may choose to select one policy from a range of related policies. The length of time it takes to generate alternative policies can range from incremental to rapid. Policy communities are networks, or "constellations of 
actors and their action in a policy sector" (Zahariadis, 1999).

The networks are linked to a greater or lesser degree. Less integrated networks tend to have breakthrough policies that are not "softened" through the process by modifying their tenets. More integrated networks tend to adopt new ideas through a longer time period or bring "softened" ideas to the forefront in a rapid manner (Zahariadis, 1999).

\section{Role of Research and Information}

Research and information are part of the policy process, but not in a deliberate, methodical way. "Studies of policy-making do suggest that it is not a linear rational-analytical process of examining all the evidence, 'reading off' the policy implications of this and then formulating well-designed interventions guaranteed to achieve the outcomes desired...research is only one factor among many competing elements in this process" (Locke, 2009). Wong identified three disincentives for policy makers to use research in their decision-making. Those are:

- The nature of pluralist democracy. Research and expert influence have some influence, but so do the opinions of interest groups and personal political allegiances and beliefs. 
- The policy making cycle. Research takes time, and the conduct of studies often doesn't align with a pressing need for convincing research findings.

- Federalism. Gaining access to data on a local or individual level often poses challenges for researchers.

- Intra-organizational politics. Governmental units vie for power, resulting in instability in the research agenda and uncertain commitment to funding (Wong, 2008).

Those involved in using information for agenda-setting may choose to be selective about the evidence they use, to misrepresent opponents' positions, or distort situations to their advantage (Sabatier, 1999).

When examining research, policy makers prefer findings that have practical consequences. They prefer quantitative over qualitative studies. "Research is helpful if it defines a problem or shows that it is worsening and needs action; identifies relationships between apparently unrelated problems; demonstrates the importance of support among the population for change; critiques current and previous attempts to solve a problem; comments on the implementation of proposed policy options; points out unexamined issues and gaps in the proposals; investigates the impact of the policy and any unintended, and especially, undesirable consequences" (Locke, 2009). 
Information also has a role in policy making. Those involved in policy "have limited time and capacity and they use information, especially statistical information, to simplify, rationalize, and explain their beliefs for policy options" (Shakespeare, 2008). One study of how information higher education policy makers use information found that different coalitions used different information sources. People within coalitions used different information sources, too. Different coalitions used the same information for different purposes. Groups had varying access to information, for instance, "those outside of the legislative process (unions, independent and proprietary institutions, and student and public interest groups) did not have the same access to the information that the executive, legislature, and public institutions did" (Shakespeare, 2008). The study found that time limitations and personal bias had an influence on information use. Constituency groups are a source of information (Shakespeare, 2008).

\section{Discussion}

This section applies the Multiple streams framework to some of the significant policy events related to information literacy in the U.S. and internationally.

Linking an issue with those that are already prominent on agendas can raise awareness and propel the issue forward 
(Gibson, 2004). Information literacy has been coupled with major problems in the policy arena. These are major societal issues that require multi-faceted and systemic solutions. They include:

- Educational reform from pre-school through higher education

- Workplace readiness of graduating students

- Lifelong learning

- An informed citizenry

- A globally competitive workforce

A number of reports have included information literacy as a necessary strategy for addressing these problems. A report issued by the U.S. National Commission on Libraries and Information Science (NCLIS), the National Forum on Information Literacy (NFIL), and the United Nations Education, Scientific, and Cultural Organization (UNESCO) linked information literacy with information and communication technologies, reducing inequities in countries and among peoples, promoting tolerance, closing the digital divide, and a competitive workforce. It related information literacy to the "Education for All" program of the United Nations (Thompson, 2003).

A 2006 report from UNESCO, NFIL, and the International Federation of Library Associations (IFLA) related information literacy to competitive advantage, economic development, lifelong learning, critical thinking, fulfilling the goals of 
the Millennium Declaration and the World Summit on the Information Society, and the empowerment of individuals and societies (Garner, 2006). A report from NFIL, OED, ETS, the Institute for a Competitive Workforce, and the National Education Association, tied information literacy as a global issue to competitive advantage, lifelong learning, and workforce preparedness (Perrault, 2006). President Obama and past member of the House of Representatives Major Owens linked information literacy to an informed citizenry (Obama, 2009; Owens, 1976).

A pivotal report published by ACRL (Association of College and Research Libraries) in 1989 is the foundation for information literacy in education today (ACRL, 1989). This report was the result of a committee formed by Dr. Patricia Senn Breivik when she was President of ACRL. The policy process streams of problems (information explosion and a critical need to have the ability to find and use information effectively) and politics (the election of a strong information literacy proponent to a national office) merged at a point in time that created a window for placing information literacy on a policy agenda.

On the national level, President Barack Obama's declaration of October 2009 as National Information Literacy Awareness Month resonated around the world. This happened as a result of 
advocacy efforts led by Dr. Lana Jackman, President of NFIL. Obama stated, "We dedicate ourselves to increasing information literacy awareness so that all citizens understand its vital importance. An informed and educated citizenry is essential to the functioning of our modern democratic society" (Obama, 2009). This policy happened as a result of the problem of the availability of an overwhelming amount of information and politics (the election of Obama, Senator Edward Kennedy, and Senator Richard Lugar; Kennedy and Lugar both advocated in a bipartisan effort to Obama for the declaration).

One way that issues can become agendas is through policy diffusion. Diffusion can happen when policies are popular or innovative (McLendon, et al., 2005). An example of a policy innovation that could be adopted by other states is California's Executive Order S-06-09. With this 2009 Order, then Governor Arnold Schwarzenegger supported the need for Information and Communications Technologies (ICT) and digital literacy. The order stated that ICT digital literacy "is a defining component of California's competitiveness for a knowledge-based economy and is growing in importance to attract capital investment that will generate higher quality jobs" (Schwarzenegger, 2009). The executive order called for the establishment of an Advisory Committee that would develop an ICT Literacy Digital Literacy 
Policy to address digital literacy in California citizens. Subsequently, California received $\$ 173.3$ million from the U.S. Department of Commerce National Telecommunications and Information Agency in American Recovery and Reinvestment Act grants. The Governor stated, "Given our state's strong commitment to broadband advances, California is helping lead the way in broadband applications for public safety, telemedicine and digital literacy for all Californians. These projects will turn the digital divide into digital opportunities for our students, our workforce, the disadvantaged and our first responders" (Gov. Schwarzenegger, 2010). Information literacy rose to a policy agenda in this situation because of the problems of economic competitiveness and the digital divide (expressed as a policy alternative, i.e., digital literacy), and the politics of an elected official who adopted the policy.

These are developments in policies related to information literacy on which other policy advocates can build.

\section{Alternative Policies}

Policy alternatives can evolve when advocates form coalitions with related groups. The ACRL Presidential Committee on Information Literacy recommended the formation of such a group in 1989. It became the National Forum on Information Literacy. NFIL is a coalition of organizations "dedicated to the global 
integration of information literacy" (Weiner, 2010). The Forum deliberately reaches out to government, healthcare, business, and education organizations outside of libraries to promote information literacy and to provide opportunities for coalitionbuilding and networking. These goals of NFIL revolve around policy issues:

- "To promote societal integration of information literacy as central to U.S. competitive advantage in the world marketplace

- To advocate for the importance of information literacy in preparing citizens for active involvement in a democratic society

- To collaborate with local, state, national, and international organizations associated with information literacy and lifelong learning" (Weiner, 2010)

NFIL promotes information literacy, but also areas that can be considered policy alternatives: critical thinking and lifelong learning. The University of California included agendas that are "alternatives" to information literacy in its report of working groups of the Commission on the Future of the University of California. Those alternatives are critical thinking ability and written communication (University of California, 2010). 
Table 1 is a timeline showing information literacy policy milestones in the U.S. It includes the dates when many national organizations adopted information literacy into pivotal documents and standards.

\section{Recommendations for Effecting Policy Changes}

The recommendations described in this section are derived from the description of information literacy policy as viewed through

the lens of the Multiple Streams framework. The purpose of these recommendations is to help those who advocate for information literacy to effect policy changes.

The Prague report identified some of the barriers to policy changes. It can be difficult to measure the impact of information literacy projects because many are short-term and specialized. The environmental factors connected with information literacy are multiple and complex, resulting in methodological issues in determining its role in causing beneficial results. Lastly, there is a consistently lack of funding and resources (Thompson, 2003). Some ways to overcome these challenges are to raise awareness of information literacy with politicians, the media, and the public. Well-designed large-scale and generalizable studies of the impact of information literacy and of the need for information literacy might be funded through government agencies and private 
foundations. These would supply critical indicators that might move information literacy onto policy agendas.

The policy process is complex and non-linear, but it is critical for researchers and stakeholders to understand (Brown, 2007). "Understanding the policy process requires a knowledge of the goals and perceptions of hundreds of actors throughout the country involving possibly very technical scientific and legal issues over periods of a decade or more when most of those actors are actively seeking to propagate their specific "spin" on events" (Sabatier, 1999). It involves paying attention to the role that debates play in legislative hearings and litigation in the process. The debates involve technical "disputes over the severity of a problem, its causes, and the probable impacts of alternative policy solutions" (Sabatier, 1999). Those who advocate for information literacy on a policy level can continually develop their knowledge of the policy process; use networks to engage those who have related interests; and maintain an awareness of related research and industry reports.

Advocates should be receptive to coupling information literacy with other reform agendas (Gibson, 2004). Policy advocates can link information literacy with other policies or problems. Those who couple issues successfully are:

- Well-connected and persistent 
- Holders of higher administrative or partisan positions

- Members of multiple arenas or institutions

- Willing to spend considerable amounts of resources (time, energy, money, etc) to make their ideas and proposals palatable to policymakers

- Present at critical meetings (Zahariadis, 1999)

Education reform and workforce readiness are high priorities, and information literacy should be included as a key competency to achieve those goals. "Many stakeholders at all levels of education have an interest in, and the expertise to promote, information literacy...information literacy has become the connective tissue that binds student learning, faculty and teacher development, community partnerships, and societal change" (Gibson, 2004).

The Prague Report provided recommendations for information literacy policy. They include:

- Demonstrate the importance of information literacy to competitive and sustainable economies.

- Establish agendas on workplace competency to include the benefits of information/knowledge as a key resource and asset .

- Provide incentives to governments, to invest in information literacy programs to enhance workforce effectiveness; and 
to employers and unions, to invest in information literacy programs.

- Include information literacy training in overseas development aid programs and in national economic development programs (Thompson, 2003).

Advocates should watch for opportunities to link issues from the policy streams. "An issue's chances of gaining prominence in the agenda are enhanced when problems and solutions or solutions and politics are joined. The issue's chances dramatically increase when all three streams-problems, policies, and politics-are coupled in a single package" (Zahariadis, 1999). An example might be the problem of education reform linked with the policy of health care reform, linked with the politics of changing elected officials. If there should be a new legislator who campaigned for education reform, and has an appreciation for the importance of health care information in the prevention of disease, that legislator might be receptive to including health and other literacies in education reform programs.

An area in which these three streams coupled is information literacy in the accreditation standards for institutions of higher education. A 2007 study of the standards from the six regional accreditation organizations in the U.S. found that all 
placed a high value on the skills associated with information literacy (Saunders, 2007). Ralph Wolff, Director of one of these organizations (the Western Association of Schools and Colleges) commented that all of the regional organizations agreed that student learning is central to accreditation. Wolff believed that "has significant implications for addressing information literacy" (Wolff, 2006). This is an example of the linking of the three streams of a problem (student learning), policy (updates of accreditation standards), and politics (leaders of accreditation organizations as advocates for information literacy in its variant forms.

Those who advocate for information literacy need to learn how to communicate effectively with policy makers. Policy makers communicate through argument, persuasion, and reasoning (Zahariadis, 1999). They use research and information, but experience overload from too much information (Birnbaum, 2000). The Alexandria and Prague reports and the report of the 2006 Information Literacy Summit are short, concise documents suitable for policy makers about the value and importance of information literacy (Garner, 2006; Thompson, 2003).

Research and information have a role in the policy process. But they must be concise and practical; help to define a problem or show that it is worsening; or identify relationships between 
unrelated problems. Those who prepare such reports must show that the constituency supports change and must critique other attempts to solve a problem. They should ensure that the research findings are accessible to the policy makers (Locke, 2009). Reports should clarify the long-term positive and negative effects of a policy (Brown, 2007). Individuals or groups can be hired to prepare information literacy briefs that can be widely disseminated.

The Alexandria report provided recommendations for policy makers for follow up. The recommendation for holding meetings around the world to facilitate the adoption of information literacy and lifelong learning strategies (Garner, 2006) was accomplished in 2008-2009 CITE. The report also recommended:

- Professional development for personnel in education, library, information, archive, and health and human services in the principles and practices of information literacy and lifelong learning

- The inclusion of information literacy in education for key economic leaders, government administrators, and advisors to business, industry, and agriculture

- Programs to increase the employability and entrepreneurial capacity of women and the disadvantaged, including 
immigrants, the underemployed and the unemployed through information literacy

- The inclusion of lifelong learning and Information Literacy in accreditation standards for education programs (Garner, $2006)$.

Another strategy is to engage those who are in mid-level positions to discuss research, policy, and practice. This can influence perspectives and agendas (Locke, 2009). Advocates can organize forums of experts that bring researchers, policymakers, managers, administrators, and practitioners together. "Brainstorming workshops leading to the identification of themes, the definition of issues, agreement of research questions and a bundle of projects to answer these within a coherent and integrated research programme and a forum to consider the interconnections between themes and to undertake foresight work" (Locke, 2009).

Since indicators can reveal a problem and measure change in a problem (Catts and Lau, 2008; Zahariadis, 1999), there is a need to develop indicators of information literacy beyond those developed by for education settings (ACRL, 2000; AASL, 2007). Information literacy is a factor not only in education, but also in work, society, education, and well-being (Garner, 2006). UNESCO provided a conceptual framework paper on developing 
information literacy indicators that is applicable globally and to all of these sectors. Catts and Lau recommend identifying indicators of information literacy through conducting secondary analyses of existing international surveys (Catts and Lau, $2008)$.

\section{Recommendations for Research}

Research that informs public policy must be rigorous and welldesigned to have credibility. Promotion and publicity about that research needs to be effective. Research questions should be understandable and useful to a broader community and scholars. Research should improve theory or policy paradigms. The conduct of studies should be transparent and meet scientific standards (Wong, 2008). These recommendations for research identify areas that would amplify the case for the information literacy agenda:

- Systematic reviews of the literature (Locke, 2009)

- How policy advocates can be effective given the inherent ambiguity (Zahariadis, 1999)

- The process of forming and implementing policy (Zahariadis, $1999)$

- The impact of information literacy on economic development, including cost benefit and value analysis of workplace information literacy programs (Thompson, 2003) 
- The impact of information literacy in profit and non-profit organizations and NGOs/Civil Society Organizations (CSOs) (Thompson, 2003)

- The relationship between information literacy and entrepreneurship (Thompson, 2003)

- Cross-state, longitudinal analysis of the determinants of postsecondary policy (McLendon, et al., 2005).

\section{Conclusion}

This paper explored information literacy policy through the lens of the Multiple Streams framework. Although focused primarily on the policy process in the U.S., the principles may be applicable to other nations. The successful strategies employed can be continued and combined with new or improved strategies based on this work. This will increase the prominence of information literacy for those who have roles in influencing policy. Research in the areas identified will strengthen the evidence base for promoting an information literacy policy agenda. 


\section{References}

AASL. (2007). Standards for the $21^{\text {st }}$ century learner. Retrieved Jan. 11, 2011, from

http://www.ala.org/ala/mgrps/divs/aasl/guidelinesandstandar ds/learningstandards/standards.cfm.

ACRL. (2000). Information literacy competency standards for higher education. Retrieved Jan. 11, 2011, from http://www.ala.org/ala/mgrps/divs/acrl/standards/informatio nliteracycompetency.cfm.

ACRL. (1989). Presidential Committee on Information Literacy: Final Report. Association of College and Research Libraries. Retrieved 1/10/2011, from http://www.ala.org/ala/mgrps/divs/acrl/publications/whitepa pers/presidential.cfm.

Birnbaum, R. (2000). Policy scholars are from Venus; policy makers are from Mars. Review of Higher Education, 23(2), $119-132$

Brown, C. P. (2007). Examining the streams of a retention policy to understand the politics of high-stakes reform. Education Policy Analysis Archives, 15(9). Retrieved Jan. 11, 2011, from http://WWw.eric.ed.gov/PDFS/EJ800838.pdf. 
Catts, R. \& Lau, J. (2008). Towards information literacy indicators. Paris: UNESCO. Retrieved Jan. 11, 2011, from http://unesdoc.unesco.org/images/0015/001587/158723e.pdf.

Garner, S.D. (2006). High-Level Colloquium on Information Literacy and Lifelong Learning, Bibliotheca Alexandrina, Alexandria, Egypt, November 6-9, 2005: Report of a meeting. Retrieved 1/7/2011, from https://docs.google.com/fileview?id=0B3SNEP9j56rIZGY3ODM4MD QtMGNiNS000TcyLTk0YmEtYjI0ODI1ZmU3ZGQ1\&hl=en .

Gibson, C. (2004). Information literacy develops globally: The role of the National Forum on Information Literacy. Knowledge Quest, 34(4), 16-18.

Gov. Schwarzenegger applauds award of over $\$ 173 \mathrm{million}$ in broadband grants. (2010). Sept. 27. Retrieved 1/8/2011, from http://www.gov38.ca.gov/press-release/16073/.

Houlihan, B. \& Green, M. (2006). The changing status of school sport and physical education: Explaining policy change. Sport, Education and Society, 11(1), 73-92.

Kingdon, J.W. (2003). Agendas, alternative, and public policies. $2^{\text {nd }}$ ed. New York: Longman. 
Locke, W. (2009). Reconnecting the research/policy/practice nexus in higher education: "Evidence-based policy' in practice in national and international contexts. Higher Education Policy, 22, 19-40.

McLendon, M.K. (2003). State governance reform of higher education: Patterns, trends, and theories of the public policy process. In J.C. Smart (Ed.), Higher education: Handbook of theory and research, vol. XVIII (pp. 57-144).

McLendon, M.K., Heller, D.E., \& Young, S.P. (2005). State postsecondary policy innovation: Politics, competition, and the interstate migration of policy ideas. Journal of Higher Education, 76(4), 363-400.

Ness, E.C. (2010). The politics of determining merit aid eligibility criteria: An analysis of the policy process. Journal of Higher Education, 81(1), 33-60.

Ness, E.C. \& Mistretta, M. A. (2009). Policy adoption in North Carolina and Tennessee: A comparative case study of lottery beneficiaries. Review of Higher Education, 32(4), 489-514. doi: $10.1353 /$ rhe.0.0086.

Obama, Barack. (2009). National Information Literacy Awareness Month, 2009. Retrieved Jan. 7, 2011, from http://www.whitehouse.gov/the_press_office/Presidential- 
Proclamation-National-Information-Literacy-AwarenessMonth/.

Ostrom, E. (1999). Institutional rational choice: An assessment of the Institutional Analysis and Development Framework. In P.A. Sabatier (Ed.), Theories of the Policy Process, (pp. 35-74). Boulder, CO: Westview Press.

Owens, M. (1976). State Government and Libraries. Library Journal, 101 (1 January 1976), 27.

Perrault, Anne Marie. (2006). American competitiveness in the Internet age: Report. https://docs.google.com/fileview?id=0B3SNEP9j56rIODA2MTI3MD ktOTE 4My00MjkwLWJhMTgtOWZkYjI 4MGQzZTVj\&hl=en （retrieved $1 / 7 / 2011)$

Sabatier, P.A. (1999). The need for better theories. In P.A. Sabatier (Ed.), Theories of the policy process (pp. 3-18). Boulder, co: Westview Press.

Saunders, L. (2007). Regional accreditation organizations' treatment of information literacy: Definitions, collaboration, and assessment. Journal of Academic Librarianship, 33(3), 317-326.

Schwarzenegger, A. (2009). Executive Order S-06-09. Retrieved 1/8/2011, from http://www. cetfund.org/node/538. 
Shakespeare, C. (2008). Uncovering information's role in the state higher education policy-making process. Educational Policy, 22(6), 875-99.

Thompson, S. (2003). Information literacy meeting of experts, Prague, the Czech Republic, September 20-23, 2003: Report of a meeting. Retrieved 1/7/2011, from https://docs.google.com/fileview?id=0B3SNEP9j56rIMjM4OGJiNW ItM2E4Ni00Yjc0LWJjYTctZDMXZTVIOGYYMDAy\&hl=en .

University of California. (2010). Commission on the future: First round of recommendations from the working groups. Retrieved Jan. 11, 2011, from http://ucfuture.universityofcalifornia.edu/presentations/co tf_wg_first_recs.pdf.

Weiner, S.A. \& Jackman, L.W. (2010). The National Forum on Information Literacy, Inc. College \& Undergraduate Libraries, 17: 1, 114-120.

Weiner, S.A. (2009). A tale of two databases: The history of federally funded systems for education and medicine. Government Information Quarterly 26(3), 450-458. doi:10.1016/j.giq.2009.02.003.

Wolff, R. (2006). Commentary: Accreditation's shift to learningcenteredness: Implications for information literacy. In 
P.S. Breivik \& E.G. Gee, Higher education in the Internet age: Libraries creating as strategic edge (pp. 13-17). Westport, CT: American Council on Education/Praeger.

Wong, K.K. (2008). Considering the politics in the research policymaking nexus. In F.M. Hess (Ed.), When research matters: How scholarship influences education policy (pp. 219-238). Cambridge, MA: Harvard University Press.

Young, T.V., Shepley, T.V., \& Song, M. (2010). Understanding agenda setting in state educational policy: An application of Kingdon's multiple streams model to the formation of state reading policy. Education Policy Analysis Archives, 18(15). Retrieved Jan. 11, 2011, from http://epaa.asu.edu/ojs/article/view/771.

Zahariadis, N. (1999). Ambiguity, time, and multiple streams. In P.A. Sabatier (Ed.), Theories of the policy process (pp. 73-96). Boulder, CO: Westview Press. 
TABLE 1. Timeline of Selected Information Literacy Policy

Milestones in the U.S. (adapted from Weiner, 2010)

1989 Association of College and Research Libraries (ACRL)

issued the report of Presidential Committee on Information

Literacy

1993 The Middle States Association of Colleges and Schools Commission on Higher Education promoted information literacy as an essential undergraduate learning outcome.

1994 The American Association of School Librarians adopted national standards on information literacy.

1997 The National Education Association made a commitment to embed information literacy in their teacher education initiatives.

1998 The American Association of School Libraries and the Association of Educational Communications and Technology published Information Literacy Standards for Student Learning for students in $\mathrm{K}-12$.

1999 The American Association of Higher Education (AAHE) endorsed the ACRL Information Literacy Competency Standards for Higher Education. 
2000 The ACRL adopted the ACRL Information Literacy Competency Standards for Higher Education.

2003 NEIL, UNESCO, and NCLIS held the first international information literacy experts meeting in Prague, resulting in the Prague Declaration (http://portal.unesco.org/ci/ en/files/19636/11228863531PragueDeclaration.pdf/PragueDecla ration.pdf).

2004 The Council of Independent Colleges endorsed the ACRL Information Literacy Competency Standards for Higher Education.

2004 The Partnership for 21st-Century Skills identified information literacy as a key student learning outcome.

2005 UNESCO/IFLA/NFIL sponsored a symposium of information literacy experts in Alexandria, Egypt, producing the Alexandria Proclamation (http://portal.unesco.org/ ci/en/ev.php-URL ID=20891\&URL DO TOPIC\&URL SECTION=201.html) .

2006 NFIL organized the first U.S. Summit on Information Literacy .

2008 The Higher Education Reauthorization Act of 2008 included information literacy as a necessary skill for teacher professional development. 
published a position statement on information literacy (http://www.aacc.nche.edu/About/Positions/Pages/ps 05052008 . aspx) .

The National Council of Teachers of English included information literacy skills in its Framework for 21stCentury Curriculum and Assessment (http://www.ncte.org/ library/NCTEFiles/Resources/Positions/Framework 21stCent Curr Assessment.pdf). President Barack Obama signed a proclamation to dedicate October as National Information Literacy Awareness Month. California Governor Arnold Schwarzenegger issued Executive Order S-06-09 to establish an Information and Communications Technology Digital Literacy Policy • 